(C) 2019. This manuscript version is made available under the CC-BY-NC-ND 4.0 license http://creativecommons.org/licenses/by-nc-nd/4.0/

\title{
GEOLOGICAL RECORD OF NATURAL EVENTS AND ANTHROPOGENIC IMPACTS ON AN INDUSTRIALIZED BAY: THE INNER ABRA OF BILBAO (NORTHERN SPAIN)
}

María Jesús Irabien ${ }^{1}$ Alejandro Cearreta ${ }^{2}$, José Gómez-Arozamena ${ }^{3}$, Humberto Serrano $^{2}$, Joan-Albert Sanchez-Cabeza ${ }^{4}$, Ana Carolina Ruiz-Fernández ${ }^{5}$

${ }^{1}$ Departamento de Mineralogía y Petrología, Facultad de Ciencia y Tecnología, Universidad del País Vasco UPV/EHU, Apartado 644, 48080 Bilbao, Spain

2Departamento de Estratigrafía y Paleontología, Facultad de Ciencia y Tecnología, Universidad del País Vasco UPV/EHU, Apartado 644, 48080 Bilbao, Spain

${ }^{3}$ Departamento de Ciencias Médicas y Quirúrgicas, Universidad de Cantabria UC, Avenida. Herrera Oria s/n, 39011 Santander, Spain

${ }^{4}$ Unidad Académica Procesos Oceánicos y Costeros, Instituto de Ciencias del Mar y Limnología, Universidad Nacional Autónoma de México, 04510 Ciudad de México, México

${ }^{5}$ Unidad Académica Mazatlán, Instituto de Ciencias del Mar y Limnología, Universidad Nacional Autónoma de México, Calz. Joel Montes Camarena s/n, 82000 Mazatlán, Sinaloa, México

Corresponding author: María Jesús Irabien

\section{ABSTRACT}

The Bilbao estuary is one of the most polluted areas on the northern coast of Spain, owing to the direct disposal of urban effluents and wastewaters from mining and industrial activities, occurred during the last 170 years. Recent sediment records collected at the inner Abra of Bilbao bay were examined using a multidisciplinary approach including geochemical, micropaleontological and isotopic proxies for evaluation of heavy metal contamination ( $\mathrm{Pb}, \mathrm{Zn}$ and $\mathrm{Cd}$ ), ecological condition (benthic foraminifera), and sediment accumulation variability $\left({ }^{210} \mathrm{~Pb}\right)$. Obtained data evidenced the interplay of both human activities and extreme weather events. Most contaminated materials are buried below a thin layer $(<25 \mathrm{~cm})$ of cleaner sediments, deposited when contaminant discharges had substantially decreased likely because of industrial reconversion and environmental regulations. However, the fingerprint left in the sedimentary record by the catastrophic floods of 1983 confirms the potential of natural 
events for sediment relocation, process that may endanger the environmental improvements achieved recently in historically polluted coastal areas.

Keywords: Metals; Benthic foraminifera; Radionuclides; Sedimentary record; Extreme floods; Environmental improvement

\section{Highlights}

- Historically polluted sediments from the estuary remain in the inner Abra of Bilbao

- Polluted deposits are gradually covered by a layer of "cleaner" sediments

- The fingerprint of extreme floods is recognized in the sedimentary record

- Both natural events and human activities may condition environmental improvement

\section{Introduction}

Estuaries are globally recognized as one of the most productive and threatened ecosystems (Robb, 2014). Over the 20th century more than $50 \%$ of the world coastal wetlands were lost owing to natural and anthropogenic factors such as land reclamation, aquaculture, navigation and shipping, dredging and filling operations, water extraction, decreased sediment input from the catchments, sea-level rise, and erosion (Kennish, 2002; Li et al., 2018). Although some changes may be locally reverted (Bowron et al., 2009; Cearreta et al., 2013; Mossman et al., 2012), most infrastructures (artificial channels, dykes, port facilities) are usually constructed on a permanent basis, leading to the definitive transformation of the original morphological and hydrodynamic features. Along with physical destruction, pollution ranks amongst the most serious and global problems. Land-based activities account for roughly $80 \%$ of pollutants released to the marine environment (World Wildlife Foundation, 2015) and, admittedly, transitional areas may act not only as a reservoir for a long list of chemicals such as trace metals, hydrocarbons, radionuclides, or organophosphorus 
compounds, but also as a potential long-term secondary source of pollution. Scavenging of pollutants can be reversible due to several factors such as diagenetic changes, bioturbation, weather events or water management actions (Ouddane et al., 2018), but major transport of pollutants from estuaries onto the continental shelf probably occurs only during floods and storms (Ridgway and Shimmield, 2002). Furthermore, coastal areas are also affected by the impact of ongoing climate change and, in particular, sea-level rise (O’Shea et al., 2018).

The multidisciplinary study of sediment cores has been extensively used to reconstruct the recent environmental transformation of coastal areas (Ruiz-Fernández et al., 2012, 2016; Baptista Neto, 2017; Polovodova Asteman et al., 2015; Sreenivasulu et al., 2017). As sediments preserve a valuable fingerprint of natural events and human impacts, sedimentary records provide useful information to reconstruct pollution histories and trends, and to facilitate long-term risk assessment and sustainable management of estuaries (Birch et al., 2013). In many countries, restrictions on waste dumping and wastewater discharges during the past decades have significantly reduced the contaminant loads to the estuarine environment (Kennish, 2002) and ameliorated sediment quality (Heim and Schwarzbauer, 2013). The Bilbao estuary (N Spain) offers a representative example of a historically polluted waterway that is undergoing significant environmental improvement (Cajaraville et al., 2016; GarcíaBarcina, 2006; Leorri et al., 2008). However, large amounts of highly polluted sediments remain stored in the estuarine bottom (Cearreta et al., 2000, 2002), mostly covered by a variable thickness layer of cleaner materials (Irabien et al., 2018). The widespread influence of human activities extends outside this estuary, as evidenced by metal accumulation areas in the continental shelf, associated to disposal sites for blast furnace slags and dredged sediments (Legorburu et al., 2013) and the anthropogenic beachrock materials that emerge eastwards adjacent to its mouth (Arrieta et al., 2017).

This is the first work to examine the recent sedimentary record at the estuary mouth (inner Abra of Bilbao bay, Figure 1) by using a multidisciplinary approach that includes 
geochemical (Pb, Zn and $\mathrm{Cd}$ ), micropaleontological (benthic foraminifera), and isotopic $\left({ }^{210} \mathrm{~Pb},{ }^{137} \mathrm{Cs}\right)$ proxies. The main aims of this study are i) to provide information about its status of environmental health, under the hypothesis that tidal cycles, sewage pollution abatement measures taken by local authorities, the industrial crisis and the derived shift of the city of Bilbao from a manufacturing to a service economy, have contributed to reduction of metal loads from the estuary, and ii) to gain insight into the impact of both human activities and natural events in the sedimentary deposits of heavily industrialized coastal areas.

\section{Study area and background}

The Bilbao estuary is a small mesotidal system located in the Basque Country $\left(43^{\circ} 23^{\prime}-43^{\circ} 14^{\prime} \mathrm{N}, 3^{\circ} 07^{\prime \prime}-2^{\circ} 55^{\prime}\right)$, on the northern Spanish coast (Figure 1). Since the first iron and steel factory started to process local ores on reclaimed salt marshes in 1854 , this waterway has been the centerpiece of economic and social growth of the Bilbao Metropolitan Area (about 900,000 inhabitants in 2019). Unfortunately, the urban and industrial expansion took place in the absence of an appropriate framework for sustainable development, so that activities such as extensive land reclamation, multiple works to ensure navigability and port activities, uncontrolled discharges of untreated wastes (mining, industrial and urban), and continuous dredgings, turned it into a largely artificial and polluted system where two main areas can be distinguished.

The upper part is formed by a narrow (50-150 m wide), shallow (4-10 m depth) and highly stratified channel (about $15 \mathrm{~km}$ long) surrounded by a dense urban and industrial network, which was described in the 1970s as a navigable sewer running through one of the most polluted cities of the world (Woodworth, 2007). The lower reaches are occupied by a funnel-shaped coastal embayment known as the Abra of Bilbao, with a total area of about $30 \mathrm{~km}^{2}$, maximum depth of $30 \mathrm{~m}$ and about $4 \mathrm{~km}$ wide (Mestres et al., 2014). It contains $95 \%$ of the total water of the estuary (Butrón et al., 2009). In the 
late 1800s, two waterbreaks were built in Santurtzi and Algorta (Figure 1) to construct an external port, dividing the bay in two main zones: the outer Abra (where most port activities develop today) and the inner Abra (area of interest of this study). These infrastructures caused a significant change in the system hydrodynamics, preventing the entrance of marine sands from the open sea into the inner Abra and thus favoring muddy sedimentation. Therefore, human-induced processes not only altered the original morphological features of the whole estuary but also the sedimentary regime (Saiz-Salinas and Urkiaga-Alberdi, 1999). As a consequence, the sandy deposits of the Las Arenas beach (Figure 1) almost disappeared and reinforcement works were carried out in the first decade of 1900 s to prevent further erosion. Later on, the construction of port facilities such as the moorings of the Real Club Marítimo (1950s), the new marina of Getxo (1999), and the jetties for large cruise ships (2006 and 2012) reduced the inner Abra bay to its current size $\left(2 \mathrm{~km}^{2}\right)$.

The recent evolution of the environmental quality of the Bilbao estuary sediments has been extensively documented (e.g., Bartolomé et al., 2006; Fdez-Ortiz de Vallejuelo et al., 2010; Irabien et al., 2018; Leorri et al., 2008; Prieto et al., 2008; SaizSalinas and González-Oreja, 1998; Seebold et al., 1982), but much less attention has been paid to the inner bay deposits. However, previous studies have detected elevated concentrations of metals in sediments from this area (Guerrero Pérez et al., 1988; Swindlehurst and Johnston, 1991), which can exert a potential risk to the environment (Belzunce et al., 2001). In 2014, enhanced contents of metals (higher than those found in 2009, 2010 and 2011) were attributed to the construction of a new jetty for long tourist cruise liners in 2012 (Rodriguez-Iruretagoiena et al., 2016).

\section{Materials and methods}

\subsection{Sampling}


Six sediment cores (between 50 and $69 \mathrm{~cm}$ length) were collected in September 2015, using a hammer corer (10 cm internal diameter) operated by scuba divers, from two transects of the inner Abra (two replicates at each sampling site; Figure 1, Table 1). All cores were described, photographed and X-radiographed before slicing into 1 cm sections.

\subsection{Sediment geochemistry}

Sediments for geochemical analysis were sieved through a 2-mm mesh, oven dried at $45^{\circ} \mathrm{C}$ and mechanically homogenized in an agate mortar and pestle. Elemental concentrations were analysed in Activation Laboratories Ltd. (Actlabs, Ontario, Canada) by Inductively Coupled Plasma-Mass Spectrometry (ICP-MS) after near total digestion using hydrofluoric, nitric, perchloric and hydrochloric acids. Lowest detection limits were $0.1 \mathrm{mg} \mathrm{kg}^{-1}$ for $\mathrm{Cd}$ and $\mathrm{Pb}$ and $1 \mathrm{mg} \mathrm{kg}^{-1}$ for $\mathrm{Zn}$.

The effect range-median (ERM) approach proposed by Long et al. (1995) was applied to assess the potential toxicological significance of metal contents determined. These reference values (220 $\mathrm{mg} \mathrm{kg}^{-1}$ for $\mathrm{Pb}, 410$ for $\mathrm{Zn}$ and 9.6 for $\mathrm{Cd}$ ) are derived from compiled biological toxicity assays and represent concentrations above which frequent adverse effects on benthic organisms are expected.

\subsection{Benthic microfauna}

Samples for foraminiferal analysis were sieved through a 63-microns mesh and washed with tap water to remove clay- and silt-size (mud) fractions. Samples were dried at $50^{\circ} \mathrm{C}$ and weighed to determine grain size percentages (sand and mud). Foraminiferal tests were concentrated by flotation in trichloroethylene and the heavy residue was examined for possible unfloated shells. Tests were picked until a representative sample of $>300$ individuals was obtained. When foraminifera were scarce, all the available tests were extracted and examined under a stereoscopic binocular microscope using reflected light. Abundance is expressed as number of 
foraminiferal tests per $15 \mathrm{~g}$ of sediment. Abundance results were grouped (very low, low, moderate, high and very high) following the quantification of absolute and relative abundances of foraminiferal tests and species for estuaries in northern Spain presented in García-Artola et al. (2016). Altogether, 185 samples and more than 38,680 foraminiferal tests were studied.

\subsection{Radiometric analysis}

Activities of ${ }^{210} \mathrm{~Pb},{ }^{226} \mathrm{Ra}$ and ${ }^{137} \mathrm{Cs}$ in cores Abra1 and Abra4 were analyzed by gamma spectrometry, using a low-background high purity germanium (HPGe) detector, in the University of Cantabria. Sediment samples were homogenized, sieved $(<0.5$ $\mathrm{mm}$ ), hermetically sealed and stored for at least 30 days to ensure secular equilibrium between ${ }^{226} \mathrm{Ra},{ }^{222} \mathrm{Rn}$ and the short-lived daughter nuclides of the latter. For sediment cores Abra2, Abra3, Abra5 and Abra6, ${ }^{210} \mathrm{~Pb}$ activities were determined through its radioactive descendent ${ }^{210} \mathrm{~Pb}$ by alpha spectrometry (Ortec-Ametek Alpha Ensemble), and ${ }^{226} \mathrm{Ra}$ and ${ }^{137} \mathrm{Cs}$ were measured by high-resolution, low-background gamma spectrometry (Ortec-Ametek HPGe well detector) in the National Autonomous University of Mexico.

Although all cores showed a downcore decreasing activity, none of the profiles was clearly exponential, indicating that accumulation rates were not constant. Therefore, age models and accumulation rates (sediment accumulation rate - SAR - and mass accumulation rates - MAR) were estimated through the Constant Flux (CF) model (Sanchez-Cabeza and Ruiz-Fernández, 2012), which assumes a constant ${ }^{210} \mathrm{~Pb}$ atmospheric flux but variable sedimentation rates. Although the CF model requires the knowledge of the total ${ }^{210} \mathrm{~Pb}_{\mathrm{ex}}$ inventory in the core, except for core Abra2 all cores showed ${ }^{210} \mathrm{~Pb}-{ }^{226} \mathrm{Ra}$ disequilibrium and ${ }^{137} \mathrm{Cs}$ activities in the bottom sections, indicating that ${ }^{210} \mathrm{~Pb}_{\mathrm{ex}}$ inventories were incomplete. 


\section{Results and discussion}

The full datasets of geochemical, microfaunal and radiometric data obtained in this work are provided in Appendices 1, 2, and 3 respectively. Concentrations of $\mathrm{Pb}, \mathrm{Zn}$ and Cd in almost all sediment samples are far in excess of those provided by Rodríguez et al. (2006) as regional background values, confirming the historical environmental impact exerted by human activities in this area.

\subsection{Transect A (cores Abra1, Abra2 and Abra3)}

The vertical distribution of all variables is broadly similar (Figure 2), allowing three different depth intervals (DIs) to be distinguished (Table 1). Sediments collected below $\sim 45 \mathrm{~cm}$ depth (DI1) show extremely high contents of metals, particularly enriched in Pb. In local pre-industrial samples (Cearreta et al., 2000) and in almost all surface sediments collected throughout the environmental monitoring programme developed in this estuary from 1997 to 2017 (Cearreta et al., 2000; Leorri et al., 2008; Irabien et al., 2018), $\mathrm{Pb}$ contents are distinctly lower than $\mathrm{Zn}$ concentrations $(\mathrm{Pb} / \mathrm{Zn}<0.35$ and 0.5 respectively). Conversely, as observed in some polluted sediments buried in the estuarine area (Irabien et al., 2018), in this interval Pb levels are similar or even exceed those of $\mathrm{Zn}(0.8<\mathrm{Pb} / \mathrm{Zn}<1.6)$, showing increased $\mathrm{Pb}$ pollution in the past.

This muddy interval (sand content median 6\%) contains very low foraminiferal abundance (32 tests/15 g) dominated by Ammonia tepida (median 28\%), Cibicidoides lobatulus (18\%), Rosalina irregularis (13\%), Bulimina gibba (11\%), Haynesina germanica (6\%), and Quinqueloculina seminula (6\%). Species number is low (7), marine foraminiferal content is high (62\%) and hyaline tests are highly dominant (91\%), with significant porcellaneous contribution (8\%).

The following zone (DI2, from $\sim 45$ to $\sim 25 \mathrm{~cm}$ depth) is characterized by the occurrence of significant grain-size changes (sandy peaks), a decrease in metal concentrations (minimum contents are at least one order of magnitude lower than those found in DI1) and $\mathrm{Pb} / \mathrm{Zn}$ ratios ranging from 0.55 to 0.8 . This sandy mud interval 
(sand content 20\%) shows the dominant presence of $A$. tepida (26\%), R. irregularis (24\%), H. germanica (16\%) and C. lobatulus (15\%). This assemblage is made of a moderate number of foraminifera (235 tests/15 g), species (15) and marine taxa (53\%) and very high hyaline tests (94\%) with lower porcellaneous content (5\%).

The ${ }^{210} \mathrm{~Pb}_{\mathrm{ex}}$ activities depth profile in the three cores exhibit a general declining trend with depth, but in this DI2 interval ${ }^{210} \mathrm{~Pb}_{\mathrm{ex}}$ activities were small or zero. Although this might suggest that DI2 was deposited more than 100 years ago, the occurrence of higher ${ }^{210} \mathrm{~Pb}_{\mathrm{ex}}$ activities below (at interval DI1) in cores Abra1 and Abra3 (unfortunately, the lower part of core Abra2 was not recovered) and the presence of ${ }^{137} \mathrm{Cs}$ in both intervals (DI1 and DI2) indicates that deposition occurred after 1952. This interval of small or zero ${ }^{210} \mathrm{~Pb}_{\mathrm{ex}}$ activities was caused by a sedimentary event transporting particles in ${ }^{210} \mathrm{~Pb}-{ }^{226} \mathrm{Ra}$ equilibrium, most likely eroded catchment soils.

Core Abra1 showed a broad equilibrium interval $(26-42 \mathrm{~cm})$. Its missing inventory was calculated by using the accumulation rate method (Sanchez-Cabeza and RuizFernández, 2012) by linear regression, and the date of this interval was compatible with the Bilbao catastrophic floods of 1983. Assuming that all equilibrium or dilution intervals in Abra2 and Abra3 (and probably Abra4, as commented below) were caused by the same event, the reference date method was used to calculate the missing inventories. The dramatic increase in mass accumulation rates and the textural and compositional changes confirms that DI2 corresponds to an extraordinary sedimentary event, caused by the worst natural catastrophe in the Basque Country's recent history, the floods of August 1983, by which significant amounts of coarse-grained and cleaner sediments arrived to the inner Abra.

Finally, the transition to the uppercore zone (DI3) is marked by a significant increase in metal concentrations (Figure 2), followed by a declining trend towards the more recent sediments. Contrary to that observed in $\mathrm{DI} 1$, levels of $\mathrm{Pb}$ are at least twofold lower than those of $\mathrm{Zn}(\mathrm{Pb} / \mathrm{Zn}<0.5)$, approaching $\mathrm{Pb} / \mathrm{Zn}$ ratios determined in surface estuarine materials monitored from 1997 to 2017 and reflecting a change in the 
anthropogenic sources over time. Sediments in DI3 were muddy again (sand content $6 \%$ ) and had a moderate foraminiferal density (210 tests/15 g) and species number (17). It is represented mainly by $A$. tepida (46\%), R. irregularis (11\%), C. lobatulus (10\%), Eggerelloides scaber (6\%) and B. gibba (5\%). Marine foraminifera (44\%) are less abundant than estuarine forms and hyaline tests continue to be highly dominant (91\%) with distinctive agglutinated test abundance (6\%).

\subsection{Transect B (cores Abra4, Abra5 and Abra6)}

Cores Abra5 and Abra6 are exclusively composed by fine-grained materials (3\% sand), while core Abra4 exhibits a noticeably increase in sandy contents below $30 \mathrm{~cm}$ depth (Figure 3).

In this basal zone of core Abra4, maximum values of MAR occur ( $40 \mathrm{~cm}$ depth), ${ }^{210} \mathrm{~Pb}_{\mathrm{ex}}$ activities remain constant and fairly low (although no zero values are reached), and $\mathrm{Pb} / \mathrm{Zn}$ ratios range from 0.6 to 0.8 . Micropaleontological features of this sandy mud interval (sand content 37\%) exhibit dominant A. tepida (36\%,), C. lobatulus (15\%), H. germanica (6\%) and $R$. irregularis (4\%), a moderate number of foraminifera (340 tests/15 g), species (20) and marine taxa (46\%), and a high abundance of hyaline tests (87\%) with secondary porcellaneous forms (12\%). Despite being less evident, all these characteristics strongly resemble to interval DI2 in cores of transect A (Figure 2), reflecting the same extraordinary sedimentary event. Likewise, the upper part of the core is broadly similar to DI3 of transect A, with lowest values of metals in near surface samples, $\mathrm{Pb} / \mathrm{Zn}$ ratios $<0.5$, an almost identical microfaunal assemblage and ${ }^{210} \mathrm{~Pb}_{\mathrm{ex}}$ activities decreasing with depth, showing regular sedimentation.

Sediments from core Abra5 show a rather homogenous granulometric distribution and increasing concentrations of metals with depth (Figure 3). In fact, bottom samples exhibit the highest concentrations of Cd found in this work. Significant peaks of this element can be also observed in all cores from transect A (Figure 2), both in downcore sediments (DI1), where $\mathrm{Pb} / \mathrm{Zn}$ ratios are above 0.8 , and in uppercore samples (DI3), 
where $\mathrm{Pb} / \mathrm{Zn}$ values are below 0.5 . As $\mathrm{Pb} / \mathrm{Zn}$ ratios in core Abra5 range from 0.4 to 0.3 , they are compatible with the upper interval DI3, suggesting recent deposition and higher sedimentation rates. Moreover, ${ }^{210} \mathrm{~Pb}$ ex activities display an almost constant and erratic profile (Figure 3). Although constant sedimentation cannot be assumed in any of the Abra cores, the CFCS model (Sanchez-Cabeza and Ruiz-Fernández, 2012) provides a rather young age $(1999 \pm 8)$ to the core bottom that confirms that sediment accumulation is high, but cannot be estimated because the regressions are not significative. According to this, the above mentioned peak of $\mathrm{Cd}$ observed in bottom samples is in good agreement with the maximum found in core Abra3 at about $15 \mathrm{~cm}$, dated in the late 1990 s $(1998 \pm 1)$.

Moreover, sediments from the whole core Abra6 are likely to belong to interval DI3, given their relatively low contents of metals, decreasing towards the surface (Figure 3), and low $\mathrm{Pb} / \mathrm{Zn}$ ratios $(<0.5)$. In this case, CFCS dating yielded a maximum core age of $1994 \pm 3$. Vertical profile of ${ }^{210} \mathrm{~Pb}_{\mathrm{ex}}$ activities reveals two recent episodes of sediment dilution, in the early 2000 s and 2008.

Finally, microfossil assemblage in Abra4 (upper muddy interval), Abra5 and Abra6 also resembled interval DI3 of cores from transect A. Foraminiferal content (292 tests/15 g) and species number (19) are moderate. Species A. tepida (50\%), B. gibba (6\%), R. irregularis (6\%), E. scaber (5\%) and C. lobatulus (4\%) are the most important forms. Marine foraminifera (38\%) are secondary compared to prevailing estuarine taxa. Hyaline tests are highly dominant (91\%) followed by similar agglutinated and porcellaneous contents.

\subsection{Historical interpretation and environmental assessment}

Based on the results obtained from geochemical, microfaunal and radiometric proxies, it is possible to distinguish three different environmental zones within the recent sedimentary record of the inner Abra bay. Firstly, the interval DI1, only identified in the cores from transect $\mathrm{A}$ (Figure 2). These muddy sediments are so enriched in $\mathrm{Pb}$ 
that concentrations of this metal in most samples exceed the upper threshold value established for "non-hazardous sediments" (1000 mg kg-1), according to the Spanish framework for the characterization of dredged materials (Buceta et al., 2015). Therefore, in the case of dredging, further studies should be carried out to determine if these sediments should to be handled as hazardous wastes or as highly polluted materials. Moreover, they also exhibit high levels of $\mathrm{Cd}$ and $\mathrm{Zn}$, which are in excess the ERM values proposed by Long et al. (1995). Highly polluted sediments with similar metal concentrations have been observed in cores from intertidal flats a few $\mathrm{km}$ upstream (Irabien et al., 2018), confirming the role of the whole area as a sink for industrial wastes. The co-occurrence of $\mathrm{Pb}$ and $\mathrm{Cd}$ indicates that they may share a common source related to the local steel mill industry (Legorburu et al., 2013). Benthic foraminifera are very scarce in this basal zone and are composed of a mixture of few marine (mainly $C$. lobatulus, $R$. irregularis and $B$. gibba) and estuarine (A. tepida) species.

The following interval (DI2) can be recognized in cores Abra1, Abra2, Abra3 and Abra4 (Figures 2 and 3). It is characterized by the accumulation of sandy layers with low concentrations of metals intercalated with muddy sediments showing variable contamination degrees, related to the arrival of materials remobilized during the extreme floods that hit the Basque Country in August 1983 (Cearreta et al., 2017). These floods were unprecedented, as the rainfall during three days (August 24, 25 and 26) equaled the monthly maximum recorded in 125 years (Instituto Geológico y Minero de España, 1986). In just 24 hours (from 9:00 AM on Friday 26 to 9:00 AM on Saturday 27) rainfall was about $500 \mathrm{~mm}$. River flow, that likely exceeded the 1000 years return period, caused generalized floods all over the region (especially in the estuarine areas, where the maximum flow coincided with high tide), 39 fatalities and economic losses of more than 800 million euro (Ocio et al., 2015).

This extreme weather event was the consequence of the interaction of warm advection through the Mediterranean with a polar air mass in high layers, which 
generated a mesoscale convective system responsible for the unusually abundant and intense rainfall (Egaña and Gaztelumendi, 2018). Known in Spain as "cold drop", this phenomenon appears to be the major regional flood threat (Ocio et al., 2015). In fact, river and flash floods exacerbated by tidal variations rank between the main identified risks that the city of Bilbao has periodically faced along its centennial history (Adán de Yarza, 1892; Landa Méndez, 2014). Unfortunately, convective phenomena in the Basque Country, leading to an increase in extreme rainfall events and floods, are predicted to increase in the future as a result of global warming (Benito et al., 2005).

The local hydrodynamic motion in the inner Abra bay is mostly tidally-induced, and the wind-wave contribution on currents is assumed to be negligible (Grifoll et al., 2009). The mean freshwater outflow is relatively low and, for larger river flows, the plume exits the estuary along the right bank and stays attached to the eastern coast (Mestres et al., 2014). However, tidal currents are diverted by the local morphology, the infrastructures and the terrestrial rotation, resulting in a clockwise current during ebb tide (and anticlockwise during high tide) (Lugaresaresti Bilbao, 1994) that contributes to the relocation of sediments during extreme meteorological events such as floods and storms.

Benthic foraminifera of the sandier DI2 interval exhibit a mixture of estuarine (mainly A. tepida and $H$. germanica) and marine hyaline species (C. lobatulus and $R$. irregularis). This assemblage highly resembles the foraminiferal species composition of the sandy Holocene sediments that characterize the lower Bilbao estuary (Leorri and Cearreta, 2004), and that could be the main source of those sandy sediments accumulated in the bay during the 1983 catastrophic flood event. However, the peaked values of metals found at about $40-45 \mathrm{~cm}$ depth in core Abra3, which coincide broadly with increased levels of ${ }^{210} \mathrm{~Pb}_{\mathrm{ex}}$, are more likely related to the arrival of remobilized polluted sediments.

Turbulent flow conditions, which wash out considerable volumes of sediment and associated contaminants, can expose anoxic sediments to oxic conditions, affecting the 
release and bioavailability of pollutants (Eggleton and Thomas, 2004). The evidence of sediment mixing in DI2 confirms that disturbances derived from extreme weather events can compound the anthropogenic impacts in coastal and marine areas (Davis et al., 2016; Ralston et al., 2013). Similarly, Ruiz and Saiz-Salinas (1999) found significant variations in the concentrations of metals in sediments and bivalves from the Bilbao estuary related to the 1989-1990 drought.

The upper core interval (DI3) represents the post-1983 period (Figures 2 and 3). Although there is a general decreasing trend in metal concentrations towards more recent sediments, high concentrations still remain in the lower part (except in core Abra6, where accumulated materials are remarkably younger). This is not surprising, given the significant improvement of the chemical quality of the sediments observed in the Bilbao estuary from 2000-2003 onwards (Leorri et al., 2008). In fact, the recent study of several cores from the estuarine area (Irabien et al., 2018) showed that the improvement in environmental conditions results in the formation of a new layer of "clean" sediments ( $<20 \mathrm{~cm}$ thickness), defined on the basis of the ERMs, that covers historically contaminated deposits. Using this approach, similar results are provided in this work, as the thickness of the "clean" layer in most cores ranges from 0 (in core Abra5 all samples exceed the ERM value for $\mathrm{Zn}$ ) to $25 \mathrm{~cm}$ (Abra6). This recent muddy interval exhibits the highest abundance of estuarine foraminifera (mainly $A$. tepida) over marine species (R. irregularis, C. lobatulus, E. scaber and B. gibba), qualitatively similar to interval DI1 but with much higher foraminiferal contents.

Our results confirm that the on-going environmental improvement in the Bilbao estuary extends to the inner Abra bay area. Therefore, future management actions (dredgings, monitored natural recovery) should take into account not only the historical legacy in the form of contaminated sites, but also the current state of the regeneration process. 


\section{Conclusions}

The sedimentary records in the inner Abra of Bilbao reflect the fingerprint of both human activities and extreme weather events. On the one hand, higher levels of contamination, derived from a long history of unsustainable development, are buried below a thin layer $(<25 \mathrm{~cm})$ of cleaner sediments deposited recently, when anthropogenic discharges had substantially decreased. Despite that polluted deposits can be somewhat hidden, their accurate characterization and risk assessment continue to challenge the current and future management of industrialized and populated coastal areas.

On the other hand, our results highlight the need to improve our understanding of the potential impact that extreme weather events (such as floods) can exert on contaminated sites, since they can remobilize sediments, promoting the release of pollutants that had been sequestered, and hindering and even reverting the environmental improvement efforts.

Acknowledgements: This research was funded by Spanish MINECO (CGL2013-41083P), UPV/EHU (UFI11/09) and EJ/GV (IT976-16) projects. Microfossil samples of cores Abra1, Abra4 and Abra6 were prepared and analyzed initially by I. Kortabitarte and A. González-Lanchas. L.H. Pérez-Bernal (UNAM) contributed to ${ }^{210} \mathrm{~Pb}$ and sediment characterization analyses. This is contribution 48 of the Geo-Q Zentroa Research Unit (Joaquín Gómez de Llarena Laboratory).

\section{References}

Adán de Yarza, R. 1892. Descripción Física y Geológica de la provincia de Vizcaya. Memorias de la Comisión del Mapa Geológico de España, 192 pp.

Arrieta, N., Iturregui, A., Martínez-Azkaraz, I., Murelaga, X., Baceta, J.I., de Diego, A., Olazabal, M.A., Madariaga, J.M. 2017. Characterization of ferruginous cements 
related to weathering of slag in a temperate anthorpogenic beachrock. Sci. Total Environ. 581-582, 49-65.

Baptista Neto, J.A., Ferreira Barreto, C., Guterres Vilela, C., Monteiro da Fonseca, E., Vaz Melo, G., Monica Barth, O. 2017. Environmental change in Guanabara Bay, SE Brazil, based in microfaunal, pollen and geochemical proxies in sedimentary cores. Ocean Coast. Manag. 143, 4-15.

Bartolomé, L., Tueros, I., Cortazar, E., Raposo, J.C., Sanz, J., Zuloaga, O., de Diego, A., Etxebarria, N., Fernandez, L.A., Madariaga, J.M. 2006. Distribution of trace organic contaminants and total mercury in sediments from the Bilbao and Urdaibai Estuaries (Bay of Biscay). Mar. Pollut. Bull. 52, 1111-1117.

Belzunce, M.J., Solaun, O., Franco, J., Valencia, V., Borja, A. 2001. Accumulation of organic matter, heavy metals and organic compounds in surface sediments along the Nervión estuary (northern Spain). Mar. Pollut. Bull. 42 1407-1411.

Benito, G., Barriendos, M., Lasat, C., Machado, M., Thorndycraft, V.R. 2005. Impactos sobre los riesgos naturales de origen climático. In: Evaluación preliminar de los impactos en España por efecto del Cambio Climático. Ministerio de Medio Ambiente.

Birch, G.F., Chang, C.H., Lee, J.H., Churchill, L.J. 2013. The use of vintage surficial sediment data and sedimentary cores to determine past and future trends in estuarine metal contamination (Sidney estuary, Australia). Sci. Total Env. 454$455,542-561$.

Bowron, T. Neatt, N., van Proosdij, D., Lundhom, J., Graham, J. 2009. Macro-tidal salt marsh ecosystem response to culvert expansion. Restor. Ecol. 19, 307-322.

Buceta, J.L., Lloret, A., Antequera, M., Obispo, R., Sierra, J., Martínez-Gil, M. 2015. Nuevo marco para la caracterización y clasificación del material dragado en España. Ribagua 2, 105-115. 
Butrón, A. Iriarte, A., Madariaga, I. 2009. Size-fractionated phytoplankton biomass, primary production and respiration in the Nervión-Ibaizabal estuary: A comparison with other nearshore coastal and estuarine ecosystems from the Bay of Biscay. Cont. Shelf Res. 29, 1088-1102.

Cajaraville, M.P., Orive, E., Villate, F., Laza-Martínez, A., Uriarte, I., Garmendia, L., Ortiz-Zarragoitia, M., Seoane, S., Iriarte, A., Marigómez, I., 2016. Health status of the Bilbao estuary: A review of data from a multidisciplinary approach. Estuar. Coast. Shelf Sci. 179, 124-134.

Cearreta, A., Irabien, M.J., Leorri, E., Yusta, I., Croudace, I.W., Cundy, A.B., 2000. Recent Anthropogenic Impacts on the Bilbao Estuary, Northern Spain: Geochemical and Microfaunal Evidence. Estuar. Coast. Shelf S. 50, 571-592.

Cearreta, A., Irabien, M.J., Ulibarri, I., Yusta, I., Croudace, I.W., Cundy, A.B., 2002. Environmental transformation of the Bilbao estuary, N. Spain: microfaunal and geochemical proxies in the recent sedimentary record. Mar. Pollut. Bull. 44, 487503.

Cearreta, A., García-Artola, A., Leorri, E., Irabien, M.J., Masque, P. 2013. Recent environmental evolution of regenerated salt marshes in the southern Bay of Biscay: Anthropogenic evidences in their sedimentary record. J. Mar. Syst. 109110 Supplement, S203-S212.

Cearreta, A., Irabien, M.J., Gómez-Arozamena, J., Kortabitarte, I., González-Lanchas, A. 2017. El registro geológico antropoceno en el Abra de Bilbao: evidencias de su historia natural y humana. Geogaceta 61, 11-14.

Davis, T. R., Harasti, D., Smith, S.D.A., Kelaher, B.P. 2016. Using modeling to predict impacts of sea level rise and increased turbidity on seagrass distribution in estuarine embayments. Estuar. Coast. Shelf Sci. 181, 294-301. 
Egaña, J., Gaztelumendi, S. 2018. A study of meteorological conditions during the historical August 1983 Basque Country floods. EMS Annual Meeting Abstracts 15, EMS2018-636.

Eggleton, J., Thomas, K.V. 2004. A review of factors affecting the release and bioavailability of contaminants during sediment disturbance events. Environ. Inter. 30, 973-980.

Fdez-Ortiz de Vallejuelo, S., Arana, G., de Diego, A., Madariaga, J.M. 2010. Risk assessment of trace metals in sediments: the case of the estuary of the NerbioiIbaizabal river (Basque Country). J. Hazard. Wastes 1-3, 565-573.

García-Artola, A., Cearreta, A., Irabien, M.J., Leorri, E., Sanchez-Cabeza, J.A., Corbett, D.R., 2016. Agricultural fingerprints in salt-marsh sediments and adaptation to sea-level rise in the eastern Cantabrian coast (N. Spain). Estuar. Coast. Shelf Sci. 171, 66-76.

Garcia-Barcina, J.M., González-Oreja, J.A., de la Sota, A., 2006. Assessing the improvement of the Bilbao estuary water quality in response to pollution abatement measures. Water Res. 40, 951-960.

Grifoll, M., Fontán, A., Ferre, L., Mader, J., González, M., Espino, M. 2009. 3D hydrodynamic characterization of a meso-tidal estuary: the case of Bilbao (northern Spain). Coast. Eng. 55, 907-918.

Guerrero Pérez, J., Rodríguez Puente, C., Jornet Sancho, A. 1988. Estudio de metales pesados en aguas y sedimentos superficiales de las costas gallegas y cantábricas, Informes Técnicos del Instituto Español de Oceanografía, 64. 16 p.

Heim, S., Schwarzbauer, J., 2013. Pollution history revealed by sedimentary records: a review. Environ. Chem. Let 11, 255-270.

Instituto Geológico y Minero de España. 1986. Estudio geológico para la previsión de riesgos por inundaciones en el País Vasco (Alava y Vizcaya) y condado de Treviño. Serie Geología Ambiental, 73 pp. 
Irabien, M.J., Cearreta, A., Serrano, H., Villasante-Marcos, V. 2018. Environmental regeneration processes in the Anthropocene: the Bilbao estuary case (northern Spain). Mar. Pollut. Bull. 135, 977-987.

Kennish, M. J. 2002. Environmental threats and environmental future of the estuaries. Environ. Conserv. 29, 78-107.

Landa Méndez, N. 2014. Adaptation to urban floods by planning and design. Guidelines for an adaptive management to urban floods and storm water use taking as a case study the City of Bilbao. Degree Project, KTH Royal Institute of $\begin{array}{llll}\text { Technology, } & 74 & \text { pp. }\end{array}$ portal.org/smash/get/diva2:727431/FULLTEXT01 (last access September 2018)

Legorburu, I., Galparsoro, I., Larreta, J., Rodríguez, J.G., Borja, A. 2013. Spatial distribution of metal accumulation areas on the continental shelf of the Basque Country (Bay of Biscay): A GIS-based project. Estuar. Coast. Shelf Sci. 134, 162173.

Leorri, E., Cearreta, A. 2004. Holocene environmental development of the Bilbao estuary, northern Spain: sequence stratigraphy and foraminiferal interpretation. Mar. Micropal. 51, 75-94.

Leorri, E., Cearreta, A., Irabien, M.J., Yusta, I. 2008. Geochemical and microfaunal proxies to assess environmental quality conditions during the recovery process of a heavily polluted estuary: The Bilbao estuary case (N. Spain). Sci. Total Environ. $396,12-27$.

Li, X., Bellerby, R., Craft, C., Widney, S.E. 2018. Coastal wetland loss, consequences and challenges for restoration. Anthropocene Coasts 1. 1-15.

Long, E.R., MacDonald, D.D., Smith, S.L., Calder, F.D., 1995. Incidence of adverse biological effects within ranges of chemical concentrations in marine and estuarine sediments. Environ. Manage. 19, 81-97. 
Lugaresaresti Bilbao, J.I. 1994. Aspectos del clima maritime y morfodinámica en el Puerto exterior de Bilbao (Shoreface morphodynamics in the Abra Bay of Bilbao, Basque Country). Kobie 22, 23-32.

Mestres, M., Sierra, J.P., Mösso, C., Sánchez-Arcilla, A., Hernáez, M. 2014. Numerical assessment of the dispersion of overspilled sediment from a dredge barge and its sensitivity to various parameters. Mar. Poll .Bull. 79, 225-235.

Mossman, H.L., Davy, A.J., Grant, A. 2012. Does managed coastal realignment create saltmarshes with "equivalent biological characteristics" to natural references sites? J. Appl. Ecol. 49, 1446-1456.

Ocio, D., Stoker, C., Eraso, A., Cowpertwait, P. 2015. Regionalized extreme flows by means of stochastic storm generation coupled with a distributed hydrological model. The case of the Basque Country. E-proceedings of the $36^{\text {th }}$ IAHR World Congress.

O'Shea, F.T., Cundy, A.B., Spencer, K.L. 2018. The contaminant legacy from historic coastal landfills and their potential as sources of diffuse pollution. Mar. Pollut. Bull. 128, 466-455.

Ouddane, B., Hamzeh, M., Daye, M. 2018 Implications of sulphide on trace metal pollution mobility in sediment. In: Recent advances in environmental science from the euro-Mediterranean and surrounding regions, 19-22. Interdisciplinary Series for Sustainable Development, Springer.

Polovodova Asteman, I., Hanslik, D., Nordberg, K. 2015. An almost completed pollution-recovery cycle reflected by sediment geochemistry and benthic foraminiferal assemblages in a Swedish-Norwegian Skagerrak fjord. Mar. Pollut. Bull. 95, 126-140

Prieto, A., Zuloaga, O., Usobiaga, A., Bartolomé, L., Fernández, L. A., Etxebarria, N., Cipriain, E., Alonso, A., 2008. Levels and spatial distribution of inorganic and 
organic contaminants in sediments along the Bilbao estuary. Mar. Pollut. Bull. 56, 2094-2099.

Ralston, D.K., Warner, J.C., Geyer, W.R., Wall, G.R. 2013. Sediment transport due to extreme events: the Hudson River estuary after tropical storms Irene and Lee. Geophys. Res. Lett. 40, 5452-5455.

Ridgway, J., Shimmield, G. 2002. Estuaries as repositories of historical contamination and their impact on shelf seas. Estuar. Coast. Shelf Sci. 55, 903-928.

Robb, C.K. 2014. Assessing the impact of human activities on British Columbia estuaries. Plos ONE 9, e99578.

Rodriguez-Iruretagoiena, A., Elejoste, N., Gredilla, A., Fdez-Ortiz de Vallejuelo, S., Arana, G., Madariaga, J.M., de Diego, A., 2016. Occurrence and geographical distribution of metals and metalloids in sediments of the Nerbioi-Ibaizabal estuary (Bilbao, Basque Country). Mar. Chem. 185, 82-90.

Ruiz, J.M., Saiz-Salinas, J.I. (1999) Extreme variation in the concentrations of trace metals in sediments and bivalves from the Bilbao estuary (Spain) caused by the 1989-90 drought. Mar. Environ. Res. 49, 1-11.

Ruiz-Fernández, A.C., Sánchez-Cabeza, J.A., Alonso-Hernández, C. MartínezHerrera, V., Pérez-Bernal, L. H., Preda, M., Hillaire-Marcel, C., Gastaud, J., Quejido-Cabezas, A.J. (2012) Effects of land use change and sediment mobilization on coastal contamination (Coatzacoalcos River, Mexico). Cont. Shelf Res. 37, 57-65.

Ruiz-Fernández, A. C., Sánchez-Cabeza, J. A., Serrato de la Peña, J. L., Pérez Bernal, L. H., Cearreta, A., Flores-Verdugo, F., Machain, M., Chamizo, E., García-Tenirio, R., Queralt, I., Dunbar, R., Mucciarone, D., Diaz Asencio, M. (2016). Accretion rates in coastal wetlands of the southeastern Gulf of California and their relationship with sea-level rise. Holocene 26, 1126-1137. 
Saiz-Salinas, J.I., González-Oreja, J.A. 1998. Coprostanol levels and organic enrichment in sediments of the Bilbao estuary (north of Spain). Oceanol. Acta 21, 319-324.

Saiz-Salinas, J.I., Urkiaga-Alberdi, J. 1999. Faunal responses to turbidity in a manmodified bay (Bilbao, Spain). Mar. Environ. Res. 47, 331-347.

Sánchez-Cabeza, J.A., Ruiz-Fernández, A.C. $2012 .{ }^{210} \mathrm{~Pb}$ sediment radiochronology: An integrated formulation and classification of dating models. Geochim. Cosmochim Acta 82, 183-200.

Seebold I., Labarta, C. Amigó, J.M. 1982. Heavy metals in the sediments of the Bilbao estuary. In: Analytical Techniques in Enviromental Chemistry, 459-463. Pergamon Press. Oxford.

Sreenivasulu, G., Jayaraju, N., Sundara Raja Reedy, B.C., Lakshmi Prasad, T., Nagalakshmi, K., Lakhsmanna, B. 2017. Foraminiferal research in coastal ecosystems in India during the past decade: a review. Geo. Res. J. 13, 38-48.

Swindlehurst, R.J., Johnston, P.A., 1991. Severe heavy metal and PAH contamination in Bilbao, Northern Spain. Greenpeace Technical Report, 19 p.

Woodworth, P., 2007. The Basque country: a cultural history. Oxford University Press.

World Wildlife Foundation. 2015. Our ocean under pressure. In: Living Blue Planet Report: Species, habitats and human well-being, 22-40. https://www.wwf.or.jp/activities/data/20150831LBPT.pdf (last access October 2018) 